\title{
Sharia compliance as the potential factor for halal tourism destination development
}

\author{
Shofiyun Nahidloh and Lailatul Qadariyah \\ Faculty of Islamic Studies, Universitas Trunojoyo Madura 69162 Indonesia. \\ Correspondence should be addressed to Shofiyun Nahidloh: Shofiyun52@gmail.com
}

Cite this: Nusantara Halal J. 2021, Vol. 2 No.1 pp. 16-23 (Article) | Received 4 March 2021 | Revised 7

May 2021 | Accepted 12 June 2021 | Published 30 June 2021 |

http://dx.doi.org/10.17977/um060.2021v2p016-023

\begin{abstract}
The substantial potential of Indonesian halal tourism expansion has obtained society's immediate attention. It is reflected in Indonesian Muslim majority society's religious enthusiasm, potentially appealing halal tourism destination resources, and the economic potential to enhance social welfare. Recently, society has put tourism as one of their needs, not as their leisure activity. Many tourists in Indonesia have been declared as halal tourism sites. However, many people perceive halal tourism as a mere trend and brand adopted due to the halal substantial, like hotels and restaurants. Therefore, a sharia principle is critically required to be the fundamental or guideline for the halal concept implementation. The halal concept can be successfully implemented if sharia compliance has expanded. Besides, the establishment of halal tourism should also follow the sharia principles to ensure the adoption of sharia values due to the considerable number of tourists. Sharia compliance becomes one of the Muslim identities, as shown from the role of the Muslim clerics on the scientific forum and research that articulate halal tourism establishment carries excellent opportunity to improve society's economy and well-being. Therefore, social compliance is the potent factor to be consistently cultivated through Indonesian halal tourism potential.
\end{abstract}

Keywords: Sharia compliance, halal tourism destination, potential factor, social compliance.

\section{Introduction}

Currently, the formal or non-formal halal certification or halal guarantee of a product has been frequently discussed in public. As the Muslim majority country, Indonesia can establish a system of halal products and tourism destinations. The discourse on this topic has also been promoted by various forums and communities that adopt halal terms, including halal tourism. The numerous tourism destinations in Indonesia create the massive potential to be developed into halal tourism. Consequently, society aspires the local and center government to enact a relevant policy that can 
be comprehensively implemented. It will bring tremendous effects on the social economy and welfare.

Tourism has been placed as one of the people's purposes and needs. Thus, the enactment of relevant regulation facilitates proper management, primarily on the society's manner on the halal tourism system and administration. Indonesia has an abundance of tourism resources, but with no intensive coaching for the business actors and users in each tourism site, the regulation will not be adequately applied. Many regions and countries have claimed to be the center of halal tourism (with more than one tourism site), but some only place the halal term as a label to attract more local and foreign tourists. Almost none of the local government policies have included training on the importance of sharia compliance for the society that has adopted halal tourism. The examples of sharia compliance implementation on the halal tourism destination are the organization management, supporting facilities and infrastructures, the provided product, the product on sale, and so forth.

Recently, the Indonesian government has instituted Law No. 33, the Year 2014, on the halal product guarantee. The law describes the halal product as the product that has been declared halal, following the sharia. It even suggests all products have this halal certification. Some universities are also advised to have the Institution of Halal Certification. This institution is expected to facilitate the audit of a product to attain the halal certification [1]. Indonesia's Muslim majority society has been the benchmark for the formally legitimated halal certification on product and non-product. The enactment of regulation will not produce significant results with no society's compliance and determination to implement the sharia consistently.

Halal certification is not a mere label or symbol that increases sales performance to generate more profit. It instead acts as the halal guarantee (the absence of the elements prohibited by the sharia or religion). As for the Muslims, sharia compliance becomes an obligation. Society demands that the halal label does not only signify the commercialization gain that aims to attain profit, but it should indicate sharia compliance. Thus, the commitment to follow Islamic teaching can be the factor that maintains society's faith toward halal labels and certification. Besides the sharia compliance adoption in the halal guarantee system, the accessible bureaucracy is also required in filing halal certification. This halal certification system should also prepare intensive education and training to maintain the commitment and consistency toward sharia compliance. Intensive training and education should also involve regulation based on Islamic teaching that substantially guides people. It also aids the government in carrying out Law No. 33, the Year 2014 on the halal product guarantee. Society's necessity on the halal guarantee is not only limited to the food and beverage product but also to the services and their management system. As the concept of halal tourism, society demands the proper halal substantial. Therefore, the sharia compliance regulation that obligates people to attend formal or non-formal intensive training and education is needed as an element to develop halal tourism destinations.

\section{Sharia Compliance}

Etymologically, the word sharia is adopted from the term syara'a (ع)ر ش), which means an object that is widely open. Then, the word sharia, that is meant the source of drinking water formed. The Arabic, later, connotes the term with a straight line to pursue [2]. Terminologically, Muhammad Ali al-Sayis translates sharia as the straight direction. It was then expanded into 'the law that rules 
human behavior from the detailed postulates.' [3]. Syekh Mahmud Syaltut defines sharia as the laws and regulations prescribed by Allah for His devotees. From those definitions, sharia can be defined as the primary and subsidiary laws on human behaviors based on Al-Qur'an and the hadiths of the Prophet [2].

The predominant sources of Islamic teaching are Al-Qur'an and hadiths. With many theorems related to an issue, a scientific methodology on sharia laws has been accurately and adequately summarized and explained. A mastery in sharia education helps people precisely comprehend AlQur'an and As-Sunnah, as taught by Muhammad SAW. Conversely, without a proper sharia comprehension, Al-Qur'an and Sunnah can be perverted and utilized in the wrong way. Thus, sharia is the key to understand Al-Qur'an and Sunnah in a proper, scientific, and Saheeh methodology. Every Muslim should better understand sharia, compared to aqeeda, morals, and other fields. Sharia and fiqh are placed in the most robust area in Islamic teaching. Even Islamic clerics are frequently referred to as someone with excellent sharia knowledge, not the other type of knowledge. Thus, sharia intelligence is essential to be comprehended. It is common for a Muslim to have no expertise in Arabic, hadith, interpretation, usul al-fiqh, and so forth. However, Muslims should comprehend sharia knowledge, especially the fiqh, even if only in a limited portion since with no fiqh comprehension, Muslims will not perform proper worship. They are not obligated to understand sharia education perfectly, but they are required to comprehend the primary part, such as the parts related to praying, marriage, taharah, and so forth [4].

In addition, compliance means following a particular standard, specification, or law that has been distinctly regulated by an authorized institution or organization. The scope of regulation can be national or international, such as international standards ruled by ISO or other national laws. Compliance represents social effects from a direct or indirect request from other people. It refers to someone's willingness level to receive or reject the inquiry from other people. One of the psychological constructs massively studies it in the social psychology field, specifically in prosocial behavior. Robert C. Cialdini is the figure who has completed a series of research through direct observation in this field [5]. In conclusion, sharia compliance can be defined as obedience toward sharia that is explained in Al-Qur'an and hadiths. Muslims are responsible for consistently complying with sharia since it becomes their need to perform worship based on their aqeeda. Sharia compliance symbolizes their submission and resignation to Allah, as their pledge to their faith as the worshiper of Allah.

The compliance toward an institution or system can be measured through legitimacy theory. The theory represents a situation where the institution's strategy is linear with the applied system so that the institution has managed to run its approach following the valid norm and rule. The implemented norm or value in an institution significantly affects the level of its users' compliance to apply that norm or value. An entity's behavior is always assumed to represent his or her willingness, classified as proper, and follow the implemented standards. Society legitimacy to an institution is an essential strategic factor for the institution's development in the future. In improving sharia compliance, some efforts are required. First, protective, through ensuring conformity toward regulation, rules, and standards adopted from analysis in the halal certification system and requirements, and during the supervision and inspection. Second, constructive, by maintaining the frugality of sources and maximum results efficiency using objective information and productive suggestion during the review on every management level. Third, consultative, by 
providing a useful recommendation for all management staff as the policy perfection to obtain the organization purpose. It is also completed to prevent all possible risks and distortion while also increase the efficacy of resource usage [6].

\section{Tourism in Sharia (Al-Qur'an and Hadiths)}

Islam is a religion that comprises all human living aspects, including aqeeda (theology), sharia (law), and morals (ethics). The sharia aspects are divided into worship (ritual) and muamallah (socio-cultural). The muamallah are specified into the factors related to God and the ones related to other human beings. Tourism can be classified into the social community and socio-cultural aspects (muamalah). In Arabic, tourism is associated with the term rihlah that means a journey or safara سار and sara. The word safara and its derivatives have been mentioned 12 times in alQur'an. Meanwhile, the term sara and its derivatives have been discussed 27 times in Al-Qur'an, such as in the surah of al-Qashash: 29; al-Thur: 10 (in the form of fi'il mudhari' and mashdar); Yusuf: 10, 19, and 109; al-Hajj: 46; al-Rum: 9 and 42; Fathir: 44; al-Mukmin: 21 and 82; Muhammad: 10; Ali Imran: 137; al-An'am: 11; al-Nahl: 36, al-Naml: 69; al-Ankabut: 20; Saba`: 18 (mentioned in the form of fi'il amr and mashdar); al-Kahfi: 47; Yunus: 22; al-Ra'd: 31; al-Naba': 20; al-Takwir: 3; Thaha: 21; and al-Maidah: 96 [7].

Islam always instructs its devotees to travel or have a journey and move away while doing kindness for the world and hereafter. It is explained in the Al-Qur'an, in the form of amr (command). Allah also commands humans to have a journey that regards and observes everything they see in detail. It is instructed in some verses below.

Say, O Prophet, "Travel throughout the land and see how He originated the creation, then Allah will bring it into being one more time. Surely Allah is the Most Capable of everything (Surah alAnkabut: 20). Have they not traveled throughout the land to see what the end of those destroyed was before them? They were far superior in might. But there is nothing that can escape Allah in the heavens or the earth. He is certainly All-Knowing, Most Capable (Surah al Fatir: 44).

Those two verses indicate that humans will attain additional value on the rihlah, followed by detailed observation (taddabur) since it reminds them of their position as Allah adherents in the earth. Thus, their rihlah carries amusement and reward from Allah. Further, Al-Qur'an also illustrates that if humans are willing to look at their surroundings, they will see the regulation applied for them in the form of the as-Sunnah. Additionally, Al-Qur'an also accentuates that a tourist destination should have security assurance and supporting infrastructures for the tourists, as mentioned by a traveler named al-Qurthubi in comprehending Surah Saba's: 18 [8].

We had also placed between them and the cities1 We showered with blessings many small towns within sight of one another. And We set moderate travel distances in between, saying, "Travel between them by day and night safely." (Q.S. Saba': 18). Therefore, supporting facilities should be provided, including security, to assure tourists' safety and comfortability during their rihlah. In relation to sharia or halal tourism, Hakim, et al. [9] argues eight standard factors of administration and management of sharia tourism, namely:

1. all provided services should pursue Islamic principles,

2. the staffs and guides should adopt discipline and respect toward Islamic principles, 
3. ensuring that all activities do not contradict Islamic principles,

4. the buildings should reflect Islamic principles,

5. the restaurants should adhere to the international standard of halal services,

6. the transportation service should be equipped with a proper security system,

7. places that facilitated tourists to worship should be provided,

8. and should not give access to areas that contravene Islamic principles.

Halal or sharia tourism are those that implement sharia in their operational management aspects and destination. In the application of sharia principles, Muslims' sharia compliance should be ensured, along with good deeds and tolerance for the followers of other religions [10]. The sharia tourism term is also frequently referred to as halal tourism. However, society has declared some opinions on this idea. During the forum group discussion (FGD), the Indonesia council of ulema (MUI) strictly explains that sharia tourism and halal tourism are held based on Al-Qur'an and used as their fundamental[11]. However, the actual reality creates different perceptions from people. One of the Indonesian figures argues that even if it is carried out based on Al-Qur'an, halal tourism provides hygienic and healthy infrastructure, such as restaurants and hotels, while sharia tourism comprehensively implements Al-Qur'an and hadiths in all its tourism aspects. The name of sharia tourism exhibits the robust sharia principal application, so it gives the impression of being less flexible. Society has already presumed that sharia and halal tourism should place Al-Qur'an and hadiths in their development and management [12].

\section{Methods}

This study used a qualitative research method that described the potential of halal and sharia tourism in Indonesia and sought to interpret the data. It was selected to investigate the sharia compliance related to the halal tourism establishment. The data were collected from some identification completed through observation, journal articles, interviews with tourism actors, results of FGD, and other references relevant to tourism and its management system [13]. The study used the phenomenology approach, which according to Creswell, is one of the qualitative approaches that observe the related participant to identify the phenomena occurring in their life. The data were collected to be translated into the meaning conveyed by the participants. Essentially, the phenomena of halal tourism development aimed to understand someone's journey in depth. Meanwhile, the sharia compliance of the tourist, business actors, and tourism destination management became the benchmark of the data collection in this study. The obtained data were described and reported in this article.

\section{Results and Discussion}

\section{Sharia Compliance in Halal Tourism Destination Development}

In the last three years, the dynamics of tourism is affected by the increase of travel between countries and economic growth, primarily in the Asia Pacific. The number of world tourists in 2014 has reached 1.110 million overseas trips, which shows a 5\% growth from the previous year. In that year, more than 300 million (27.1\% of the total number of world tourists) went to Asia, of which 96.7\% went to Southeast Asia. Meanwhile, in 2015, the world tourist journey still grew by $4.5 \%$ during the unstable global situation. That growth is still considered as significant. The global economy started to enhance in 2016 and became the driving factor of tourism growth. Similarly, 
Indonesia also recorded 9.3 million tourists in 2014 and 10.4 million in 2015 (increased by 2.9\%), while foreign tourists reached 12 million in 2016.

Compared to the other Southeast Asia countries, Indonesia has been placed in the fourth rank of tourism country below Thailand, Malaysia, and Singapore. If observed from the tourist nationality, Singaporean, Malaysian, and Chinese people become the three most significant foreign tourist contributors in Indonesia; meanwhile, the top three non-Asian tourists come from Australia, England, and the United States of America [14]. With this massive advancement in tourism, the public has paid particular attention to the expansion of the national and international halal tourism destinations. The improvement of the halal tourism industry brings an increase in Islamic economic development. Therefore, society's sharia compliance aids the implementation of regulation and the concept of halal tourism in some destinations. The term halal in the tourism industry will not be perceived as a label or even commercialization anymore if it is equipped with maximum management and supervision.

\section{Sharia Compliance in Halal Tourism Management Efficacy}

Sharia compliance in the halal tourism management in each destination is crucial since Indonesia has an abundance of tourism potential ranging from a beautiful panoramic view to its great ocean. Halal tourism concept carries some requirements, such as Islamic organization management, sufficient worship places, separated toilets that fulfill the standard of sanctity, an activity limitation among men and women, and so forth. These regulations result in the comfort of domestic and foreign tourists. Furthermore, Al-Qur'an also explains that if humans are willing to pay proper consideration, they will notice that some requirements are implemented within their environment and themselves (physically and spiritually) (as-Sunnah). In the other parts, AlQur'an also emphasizes the importance of security assurance and supporting infrastructure in a destination. Therefore, a comfortable and secure atmosphere for domestic and foreign tourists is composed. The sharia compliance should be practiced by the tourists, along with all tourism elements, such as an investor, management, staffs, and other related business actors)

Indonesia is placed in the $50^{\text {th }}$ world position in the tourism competitiveness aspect since its tourist number continuously increases. The improvement in the tourism sector enhances the economic activity and the local society's welfare. The halal tourism concept will be maximally adopted if supported by sharia compliance of the community. That way, it will generate significant opportunities for local and foreign investors. It is enhanced by society's consistency and commitment in managing the various natural beauties and potential while also practice the sharia provision as part of their worship.

\section{Sharia Compliance in the Tourism Human Resources Activity}

The Director-General of Tourism Marketing will conduct human resources training, capacity building, and socialization. Besides, the government also gathers information from other countries which have implemented the halal tourism concept, such as Malaysia, while also held socialization and communication with the Association of Indonesia Tourism Actors (ASPRI) to ensure the halal level of each destination. Halal tourism requires the assistance of facilities and services provided by the surrounding society, local, and central government that follow the sharia principles. Thus, coaching and education on sharia compliance are also needed. Many people 
choose halal tourism since it gives products and services that reflect sharia value. Therefore, the human resources involved in this sector should comprehend and has the commitment to practice sharia in their activity. The previous government formulated activity should be carried out, while the human resources in the tourism businesses should be intensively educated and trained.

Islamic teaching places a journey or travel as a part of worship, as the practice of hadj and umrah as commanded in the fifth pillars of Islam. Besides, in Islam, traveling is also counted as knowledge and learning sources, or invitation to worship Allah (Qur'an Surah At-Taubah:112, al-An'am: 1112, al-Naml: 69-70). The tourism activity demonstrates worship to Allah and the sharia compliance practice.

\section{Sharia Compliance as Tourist Attraction in society business or Small and Medium Enterprises Empowerment}

Within the Indonesia Law No. 10, The Year 2009 regulates the tourism attraction, area, transportation service, tour, food, and beverage provider, accommodation, entertainment, and recreational activity, meeting organizer, intensive tour, conference and exhibition, tourism information service, tourism consultation, tour guide, and spa. The tourism development is carried out following the integral national, provincial, and local tourism development master plan. Indonesian tourism laws also declare that tourism functions to fulfill the tourists' physical, spiritual, and intellectual needs while also increasing the country's revenue in realizing society welfare.

In the explanation of Indonesia Law No. 10, the Year 2009 on tourism, sharia compliance is positioned as an element that easily enhances the attractiveness in the small and medium enterprises (SMEs) field. The related business actors that practice sharia compliance helps the tourist to trust their service and feel secure in purchasing the product. Thus, sharia compliance should be adopted by the SMEs to ensure the improvement of Islamic creative economy activity and social well-being since it reduces unemployment and poverty rate. It is all disembogued on the consistency to practice sharia values that become the principle of Islamic aqeeda. The security and convenience of the tourism destination are appreciated by both Muslim and non-Muslim tourists since it puts sharia values as rahmatal lil 'alamin. As described by the Indonesia Council of Ulema, halal tourism should promote halal and safe products consumed by Muslim tourists. However, non-Muslim tourists can also produce the products. In 2014, the ministry and Indonesia Council of Ulema tried to formulate the halal standards, but it has not been effective. Sharia compliance holds an essential role to be enforced. The Indonesia Council of Ulema has emphasized that sharia tourism is part of da'wah for Muslims, while it becomes healthy and safe tourism for non-Muslim since it has passed observation from the Indonesia National Agency of Drugs and Food Control (BPOM). The enactment of Law No. 33, the Year 2014 on the halal product guarantee, describes that all products should have halal certification to be more appealing for the consumers in the tourism or SME sectors.

\section{Conclusions}

Halal tourism destinations can be established by maximally implement sharia compliance. Society's sharia compliance creates substantial opportunity and power within halal tourism development. Halal tourism should always regard sharia compliance and implement sharia values. Indonesia has strong and numerous natural and cultural potential, along with the iconic 
Muslim majority religious tourism. These considerable halal tourism potentials can be enhanced by (1) sharia compliance in the tourism destination development; (2) sharia compliance in halal tourism management efficacy; (3) sharia compliance in the tourism human resources activity; (4) sharia compliance as the tourist attraction in the social business or SMEs since most of the tourist in visit the religious destination in the top 50 tourism destination in Indonesia. Sharia compliance becomes one of the Muslim identities, as proven from the Islamic clerics' role in the scientific forums and studies that declare the establishment of halal tourism destinations carries substantial opportunity to enhance society's economy and well-being. Therefore, sharia compliance is a robust factor in developing halal tourism destinations in Indonesia.

\section{References}

[1] N. Nifasri, "Kewenangan BPJH dalam pengajuan sertifikasi Halal," 2018.

[2] I. Zakariyah and A. H. A. bin Faris, "Mu'jam Maqayis al-Lughah, Juz III," Mesir: Dar al-Fikr wa al-Nasyr wa al-Tusi. 1979.

[3] M. Qaththan, “Al-Tasyrī’Wa al-Fiqh Fī al-Islāmi Tārīkhā Wa Manhajā,” Beirut: Muassasah alRisālah. 1982.

[4] A. Zain, "Dakwah dalam perspektif Al-Quran dan Al-Hadits," At-Taujih Bimbing. dan Konseling Islam, vol. 2, no. 1, pp. 40-53, 2019.

[5] A. K. Munthe, I. S. Praramadhani, and R. I. Satrya, "Peran dewan pengawas syariah dalam pemenuhan Syariah Compliance oleh Lembaga Keuangan Syariah,” J. Islam. Law Stud., vol. 2, no. 3, pp. 1-26, 2021.

[6] S. R. Kasim and R. Bukido, "Urgensi hukum kepatuhan Syariah dalam perbankan Syariah di Indonesia," Potret Pemikir., vol. 22, no. 2, pp. 1-14, 2018.

[7] R. Syahriza, "Pariwisata berbasis Syariah (telaah makna kata sara dan derivasinya dalam alQur'an)," Hum. Falah J. Ekon. Dan Bisnis Islam, vol. 1, no. 2, pp. 135-145, 2014.

[8] A. A. M. B. Al-Qurtubi and A. Al-Ansari, "al-Jami'li Ahkam al-Quran.” Mu'assasat al-Risalah, Beirut:, 1969.

[9] A. Abd Hakim, H. Ridwan, M. Hasanuddin, and S. Al-Hakim, "Towards Indonesia Halal tourism," AHKAM J. Ilmu Syariah, vol. 17, no. 2, pp. 279-300, 2017.

[10] M. J. Ahmed and A. Akbaba, "The potential of Halal tourism in Ethiopia: Opportunities, challenges and prospects," Int. J. Contemp. Tour. Res., vol. 2, no. 1, pp. 13-22, 2018.

[11] S. Chairunnisyah, "Peran Majelis Ulama Indonesia dalam menerbitkan sertifikat Halal pada produk makanan dan kosmetika," EduTech J. Ilmu Pendidik. dan Ilmu Sos., vol. 3, no. 2, pp. 6475, 2017.

[12] M. Battour and M. N. Ismail, "Halal tourism: Concepts, practises, challenges and future," Tour. Manag. Perspect., vol. 19, pp. 150-154, 2016.

[13] S. Arikunto, Metode penelitian kuantitatif, kualitatif, dan kombinasi (mixed methods). Bandung: Alfabeta, 2014.

[14] A. Jaelani, "Islamic tourism development in Cirebon: The study heritage tourism in Islamic economic perspective," J. Econ. Bibliogr., vol. 3, no. 2, pp. 1-24, 2016.

\section{Corresponding author biography}

Shofiyun Nahidhloh graduated from Universitas Islam Negeri Sunan Ampel (formerly IAIN Sunan Ampel) Surabaya, Indonesia in 2009. Currently, she is an Associate Professor and she also serves as a Dean of Faculty of Islamic Studies at Universitas Trunujoyo Madura, Indonesia. Her research interest is in sharia halal business law as well as tourism and the halal industry. 